\title{
Michał Igielski
}

Akademia Morska w Gdyni

e-mail: m.igielski@wpit.am.gdynia.pl

\section{MODEL WSPARCIA POSTAW PRZEDSIĘBIORCZYCH ABSOLWENTÓW SZKÓŁ WYŻSZYCH - PROGRAM ROZWOJU KOMPETENCJI}

\section{THE MODEL OF SUPPORTING ENTREPRENEURIAL ATTITUDES OF UNIVERSITY GRADUATES - A COMPETENCE DEVELOPMENT PROGRAMME}

DOI: $10.15611 /$ pn.2017.499.10

JEL Classification: L26

Streszczenie: W grupie ludzi łatwo można zaobserwować, że na daną sytuację każda z osób reaguje we właściwy sobie sposób. Zazwyczaj ten typ reakcji powtarza się - jest to postawa. Postawy mogą ulegać zmianom, na przykład pod wpływem osoby mającej autorytet lub też cieszącej się zaufaniem. Z kolei dla wszystkich chcących być postrzeganymi jako osoby przedsiębiorcze ważna jest gotowość do podejmowania ryzyka, asertywność, przejawianie inicjatywy, kreatywność czy też samoakceptacja. Ale czy na pewno? Ostatnie przemiany gospodarcze, spotęgowane postępującą globalizacją, wskazują na nowe umiejętności i postawy stające się coraz bardziej pożądane w XXI w. Jest to istotne w przypadku studentów, który częściej postrzegają siebie w roli pracownika niż pracodawcy. Celem opracowania jest przedstawienie Programu rozwoju kompetencji, stworzonego przez Akademię Morską w Gdyni w ramach projektu dofinansowanego z UE, który skierowany jest do absolwentów szkół wyższych.

Słowa kluczowe: przedsiębiorczość, postawy przedsiębiorcze, rozwój kompetencji.

Summary: In a group of people it is easy for us to see that each person can react differently to a given situation. Usually this type of reaction is repeated and this is the attitude. These attitudes can change, for example, under the influence of a person with authority or trust. On the other hand, for everyone who wants to see them as entrepreneurial people, it is important to be willing to take risks, assertiveness, initiative, creativity or self-acceptance. But is it for sure? Recent economic changes, exacerbated by increasing globalisation, point to new skills and attitudes that are increasingly desirable in the 21 st century. This is all the more important in the case of students, as these people still see themselves more often as employees than as employers. Therefore, the aim of the study is to present the Competence Development Programme, created by the Maritime Academy in Gdynia as part of a project co-financed by the EU, which is addressed to university graduates.

Keywords: entrepreneurship, entrepreneurial attitudes, competence development. 


\section{Wstęp}

Ostatnie przemiany gospodarcze, spotęgowane postępującą globalizacją, potwierdzone badaniami rynku pracy oraz analizą oczekiwań większości pracodawców, wskazują na nowe umiejętności i postawy - postawy przedsiębiorcze, które stają się coraz bardziej pożądane w XXI wieku, a które są zazwyczaj właściwe dla nielicznych pracowników. Samą przedsiębiorczość najprościej można określić jako umiejętność radzenia sobie w różnych sytuacjach życiowych i można powiązać ją z poszukiwaniem i wdrażaniem nowych form rozwoju oraz ze zmianą statusu społecznego przez niezwykle aktywne jednostki, społeczeństwa, narody.

Nie jest to jednak kwestia bardzo aktualna, gdyż nowe oczekiwania odnośnie do kadr zostały dostrzeżone przez polskich pracodawców już na początku lat 90., na starcie polskiej transformacji. A. Maciejczyk, przedstawiciel Konfederacji Pracodawców Polskich, wskazywał, iż w obliczu coraz większego udziału pracowników w procesach zarządzania oczekuje się od nich twórczego myślenia wyrażającego umiejętności planowania, analizowania i oceniania rezultatów własnej pracy, odpowiedzialności, samodzielności oraz umiejętności wyciągania wniosków z własnych sukcesów i porażek, jak również ciągłego uczenia się. Podkreślał również znaczenie przedsiębiorczości zarówno pracowników, jak i właścicieli przedsiębiorstw [Maciejczyk 1996, s. 78-80].

Ta kwestia wydaje się szczególnie ważna w odniesieniu do studentów czy też absolwentów, którzy stopniowo wkraczają na rynek pracy. Przecież uczelnie w XXI wieku, w erze gospodarki opartej na wiedzy, nie mogą być nastawione tylko i wyłącznie na działalność dydaktyczną, ale przede wszystkim na kreowanie umiejętności przydatnych na współczesnym rynku gospodarczym. W związku z tym celem artykułu jest przedstawienie Programu rozwoju kompetencji, stworzonego przez Akademię Morską w Gdyni, w ramach projektu dofinansowanego ze środków Unii Europejskiej ${ }^{1}$.

\footnotetext{
${ }^{1}$ Projekt „Rejs do kariery” realizowany był przez Akademię Morską w Gdyni w latach 2013-2016, w ramach Programu operacyjnego „Kapitał ludzki”, priorytet VI - Rynek pracy otwarty dla wszystkich, działanie 6.4 - Projekty innowacyjne. Celem ogólnym projektu było wprowadzenie efektywnej metody (modelu) przygotowania studentów ostatniego roku nauki na uczelniach wyższych do wejścia na rynek pracy w roli pracownika i pracodawcy oraz poprawa ich elastyczności. Wymiarem docelowym miało być zwiększenie wśród absolwentów uczelni wyższych umiejętności poruszania się po rynku pracy, zwiększenie efektywności poszukiwań pierwszego zatrudnienia, a co za tym idzie zmniejszenie poziomu bezrobocia wśród tej grupy. Ma to również istotne znaczenie dla rozwoju powiązań między nauką a przedsiębiorcami. W celu pełnego wykorzystania istniejącego potencjału studentów, pobudzenia w nich przedsiębiorczości oraz zachęcenia ich do proinnowacyjnych zachowań zaplanowano w projekcie kompleksowe działania mające na celu stworzenie wielopłaszczyznowego modelu wparcia właśnie tej grupy osób.
} 


\section{Istota postaw przedsiębiorczych}

Przedsiębiorczość może być rozumiana na trzy sposoby. W pierwszym przypadku jest interpretowana jako postawa (dla której istotne znaczenie mają cechy przedsiębiorcy, jego osobowość, predyspozycje, wiedza, sposoby reakcji oraz gotowość do podejmowania działań), która ma bezpośredni wpływ na zachowania przedsiębiorcy, jego gotowość do podejmowania nowych działań, modyfikacji dotychczasowych czy aktywnego poszukiwania modyfikacji aktualnych stanów rzeczy. Drugi aspekt to zachowanie przejawiające się zdolnością do wykorzystywania pomysłów i nowych możliwości czy nadarzających się okazji pomijanych przez innych. Z kolei przedsiębiorczość rozumiana jako proces odnosi się do tworzenia nowych przedsięwzięć [Piecuch 2010, s. 37-44].

W grupie ludzi łatwo można zaobserwować, że na określoną sytuację każdy z jej członków reaguje we właściwy sobie sposób. Zazwyczaj ten typ reakcji się powtarza - jest to postawa. W ujęciu psychologicznym przez postawę należy rozumieć pewne określone, stale powtarzające się schematy, według których jednostka czuje, myśli i działa. Na postawy składają się emocje, myśli oraz predyspozycje do działania. Postawy mogą ulegać zmianom, na przykład pod wpływem osoby mającej autorytet lub cieszącej się zaufaniem otoczenia. Zmiana postaw może też nastąpić w wyniku długotrwałego procesu wychowawczego, a także oddziaływania mediów (wiele osób rzuciło palenie pod wpływem kampanii antynikotynowej). W kontaktach z innymi ludźmi, jeżeli pragnie się osiągnąć zamierzone cele, nie można być ani nadmiernie uległym, ani agresywnym. Powodzenie zapewnia postawa pośrednia, zwana asertywną. Praca zawodowa, realizacja ambitnych przedsięwzięć wymagają przejawiania inicjatywy i kreatywności. Aby być w zgodzie z własnym sumieniem i obowiązującymi normami, człowiek przedsiębiorczy powinien wykazywać się odpowiedzialnością i uczciwością. Jednym $\mathrm{z}$ warunków zachowań asertywnych jest samoakceptacja [Klonowska-Matynia, Palinkiewicz 2013, s. 30-30].

Samoakceptacja pozwala czuć się bardziej pewnie. Osoby asertywne w sposób zdecydowany potrafią bronić swoich praw, nie naruszając jednak uprawnień innych ludzi. Dodatkowo ludzi aktywnych cechuje inicjatywność, czyli zdolność do rozpoczynania działań, występowania z pomysłami. Ludzie ci są też kreatywni - zdolni do twórczego myślenia, przełamywania stereotypów i znajdowania rozwiązań, które do tej pory nie były znane lub stosowano je w innych sytuacjach.

Dla wszystkich chcących być postrzeganymi jako osoby przedsiębiorcze, równie ważna jest gotowość do podejmowania ryzyka, ale oczywiście po wcześniejszej analizie wszystkich wariantów i wyborze najkorzystniejszego. Jest to ściśle powiązane z odpowiedzialnością, która musi być cechą osoby przedsiębiorczej. Każdy z nas bowiem musi w sposób odpowiedzialny wywiązywać się ze swoich obowiązków, co także łączy się z uczciwością. Odpowiedzialność i uczciwość powinny więc charak- 
teryzować każdego człowieka, ale w wypadku osób prowadzących własne przedsiębiorstwo są one niezbędne, ponieważ czynią firmę wiarygodną w oczach innych partnerów, a w konsekwencji budują jej pozytywny wizerunek.

Można też wnioskować, że przede wszystkim bogate doświadczenie może skutkować podejmowaniem inicjatyw gospodarczych. Peter Drucker podaje praktyczne przykłady osób, które stały się innowatorami dopiero na emeryturze, wykorzystując swoje bogate zawodowe doświadczenie. $Z$ drugiej jednak strony zachowanie przedsiębiorcy jest rezultatem przypadkowo wywołanych impulsów (instynktu, szczęścia) oraz umiejętności przetwarzania rynkowych informacji. Można uznać, że przedsiębiorczość jest cechą działania osób z różnych grup wiekowych, z różnym doświadczeniem i motywacją [Targalski, Kosała, Pichur 2007, s. 93].

W literaturze człowiek przedsiębiorczy definiowany jest jako osoba, która [Gibb 1996]:

- jest pionierem, podejmuje się działań nowych, nierutynowych,

- lubi przygodę i działanie w warunkach niepewności,

- myśli i działa niezależnie, jest odważna i nastawiona optymistycznie,

- przywiązuje wagę do własnego rozwoju,

- jest pewna siebie, świadoma swoich mocnych i słabych stron,

- jest ambitna, wykazuje inicjatywę w działaniu,

- jest odpowiedzialna w pracy i przy wykonywaniu działań,

- jest kreatywna i przekonująca.

Z punktu widzenia rozwoju przedsiębiorczości duże znaczenie mają postawy wobec prowadzenia własnej działalności gospodarczej. Na ich kształtowanie wpływają zarówno uwarunkowania tkwiące w szeroko rozumianym otoczeniu potencjalnego przedsiębiorcy, jak i czynniki wewnętrzne, związane z osobowością, przekonaniami czy samooceną posiadanych kompetencji [Arent, Walczyna 2015, s. 9].

Można powiedzieć, że postawę przedsiębiorczą charakteryzują m.in. przejawianie własnej inicjatywy, aktywność czy też niezależność, połączona z innowacyjnością zarówno w miejscu pracy, jak i w życiu prywatnym. Nie można też powiedzieć, by kształtowanie postaw przedsiębiorczych miało wyodrębniony charakter w postaci jednego lub kilku przedmiotów - nie ma ono przecież na celu bezpośrednio przygotowania do bycia przedsiębiorcą (właścicielem firmy lub jej menedżerem). P. Drucker wskazuje [1992, s. 18], że przedsiębiorczość w organizacji jest kwestią praktyki, motywacji bardziej niż osobowości. Jest pracą. Natomiast M. Minniti i W. Bygrave twierdzą, że przedsiębiorczość bazuje na ciągłym i niekończącym się procesie uczenia przez działanie (learning by doing). Przedsiębiorca czerpie swoją wiedzę tak z sukcesów, jak i z porażek rynkowych. Zdaniem autora opracowania kształtowanie postaw przedsiębiorczych to przede wszystkim sztuka stymulowania rozwoju umiejętności myślenia oraz działania przedsiębiorczego połączona z prezentacją postaw sprzyjających podejmowaniu takich właśnie działań, które z kolei mogą odzwierciedlać się w określonym poziomie zaangażowania w sytuację pracy, 
w pomysłach racjonalizatorskich, udoskonaleniach, inicjatywności i innowacyjności. Przecież człowiek, który wykazuje się postawą przedsiębiorczą, wychodzi poza schemat danego zadania, wykazując przy tym postawę refleksyjną, czyli umiejętność rozpoznawania wzajemnych zależności między swoją pracą a pracą innych.

\section{A może własna firma? - analiza postaw przedsiębiorczych studentów na rynku pomorskim (na podstawie danych Urzędu Marszałkowskiego Województwa Pomorskiego zebranych przez Pentor International Poznańn $)$}

Z analizy badania zleconego przez Urząd Marszałkowski Województwa Pomorskiego wynika, że studenci z Pomorza nie są aktywni zawodowo w obszarze praktyk i staży studenckich. Jednakże zintensyfikowała się ich aktywność na polu sezonowej i regularnej pracy zawodowej w trakcie studiów. Niemal co trzeci badany przyznał, że $\mathrm{w}$ chwili badania jest gdzieś zatrudniony.

Z badania wynika, że studenci widzą się częściej w roli pracowników niż pracodawców. Badani absolwenci, mówiąc o swoich planach zawodowych, stwierdzają, że są najbardziej zainteresowani uzyskaniem zatrudnienia na zasadach umowy o pracę. Aż $80 \%$ wskazań w pytaniu o plany zawodowe dotyczy zawarcia umowy o pracę po studiach. Zauważa się jednak wśród studentów potencjał do rozwijania przedsiębiorczości. Należy pamiętać, że jest to wynik niższy niż w poprzednim pomiarze oraz mieć na względzie, że na razie są to często jedynie deklaracje, a nie ostatecznie podjęte decyzje. Jedynie co piąty badany student wskazał, że po ukończeniu studiów myśli o tym, że założy własną firmę. Ponad połowa badanych przyznała, że ma pomysł na własny biznes, z czego już tylko 1/6 twierdziła, że zdecydowanie ma już pomysł na firmę. Znaczna część badanych nie potrafiła jednak odpowiedzieć na to pytanie. Analizując zebrane dane, nasuwa się wniosek, że część studentów, która deklaruje założenie własnej firmy, nie jest jeszcze pewna swojej decyzji oraz że są to częściej deklaracje, a nie ostateczne, przemyślane decyzje.

Co dziwne, prawie połowa deklarujących chęć założenia własnej działalności nie potrafi sprecyzować, kiedy dokładnie to uczyni. Często wskazywany przez osoby planujące założenie firmy brak nawet przybliżonego terminu oraz pomysłu na otwarcie własnej firmy świadczy o jedynie deklaratywnym charakterze odpowiedzi,

2 Badanie z 2015 roku pt. ,Studenci ostatniego roku szkół wyższych - pracodawcy czy pracownicy?”, przeprowadzone na reprezentatywnej próbie 5521 studentów ostatniego roku studiów stacjonarnych (dziennych) magisterskich i licencjackich większości szkół wyższych (23 szkoły wyższe, zarówno publiczne, jak i prywatne) w województwie pomorskim. Zrealizowano je na przełomie kwietnia i maja 2015 roku. Badanie przeprowadzono metodą ilościową za pomocą techniki ankiety audytoryjnej. Głównym celem badania było określenie potencjału do rozwoju przedsiębiorczości w regionie. Ponadto badano postawy absolwentów szkół wyższych wobec wyzwań na rynku pracy i kształtowania możliwości własnego rozwoju zawodowego, które są jednym z elementów wpływających na warunki rozwoju regionu. 
co może dowodzić, że część z tych osób podąży inną ścieżką kariery zawodowej. Podobnie wygląda sytuacja, jeśli chodzi o podjęcie konkretnych działań związanych z założeniem własnej firmy - blisko połowa badanych wskazała, że jeszcze nie podjęła tego typu działań.

Osoby wchodzące powoli na rynek pracy planują otwarcie firmy w dość zróżnicowanych branżach. Badani najczęściej zamierzają działać w takich obszarach, jak: informatyka - produkcja sprzętu, programowanie, tworzenie stron internetowych, służba zdrowia, opieka zdrowotna i społeczna, handel hurtowy i detaliczny, działalność w sferze edukacyjnej, budownictwo i remonty budowlane, działalność na rynku nieruchomości. 3/4 studentów, którzy zamierzają otworzyć firmę, oświadcza, że planowana branża będzie zgodna z kierunkiem studiów. Oznacza to, że znaczna część studentów traktuje ukończony kierunek studiów jako profil, który chcieliby kontynuować w swojej pracy zawodowej. Jest to zmiana w porównaniu z poprzednią edycją badania, kiedy to absolwenci rzadziej wskazywali na kontynuację swojego profilu studiów w przyszłej działalności gospodarczej.

Wpływ na decyzję o prowadzeniu własnego biznesu mają najczęściej własne zainteresowania, wiedza i pomysły badanych, następnie analiza rynkowych potrzeb oraz, co nowe w aktualnym badaniu, porady i sukces innego przedsiębiorstwa. Znacznie rzadziej przyczyniają się do tego zajęcia na uczelni. Najczęstsze obawy związane z prowadzeniem własnej działalności gospodarczej dotyczą kwestii finansowych: kosztów związanych z prowadzeniem firmy, a także braku możliwości spłaty kredytu. Respondenci mniej obawiają się biurokracji i braku funduszy własnych, natomiast znacznie bardziej - kosztów prowadzenia własnej działalności.

\section{Opis innowacyjnego narzędzia - Program rozwoju kompetencji}

Na wstępie należy zaznaczyć, że model wsparcia studentów wchodzących na rynek pracy, powstały w wyniku realizacji projektu „Rejs do kariery”, ma duży potencjał wdrożeniowy. Nie są wymagane żadne zmiany prawne ani organizacyjne na uczelniach, aby móc wdrożyć na nich testowany model. Zdaniem jego twórców istnieje możliwość wdrożenia go do głównego nurtu praktyki akademickich biur karier polskich uczelni. Potwierdziło to badanie/wdrożenie pilotażowe, w którym udział wzięło 45 studentów (25 kobiet i 20 mężczyzn) z trzech pomorskich uczelni: Akademii Morskiej, Uniwersytetu Gdańskiego oraz Szkoły Wyższej Psychologii Społecznej w Sopocie. 95\% studentów, czyli zdecydowana większość, oceniła model wsparcia w projekcie jako skuteczny z punktu widzenia ich wchodzenia na rynek pracy. Spośród studentów biorących udział w projekcie blisko 40\% osób, które wypełniły ankietę ewaluacyjną, pracuje na umowę o pracę lub umowę o dzieło czy zlecenie; część z tych osób swoje zatrudnienie wiąże m.in. ze wsparciem uzyskanym w ramach modelu.

Program rozwoju kompetencji nie jest skomplikowanym produktem - jego prostota jest jedną z jego największych zalet. Dzięki temu, że model można łatwo opi- 
sać, a jego założenia przedstawić na krótkiej broszurze informacyjnej, jego potencjał wdrożeniowy jest bardzo duży. Użytkownicy, czyli pracownicy akademickich biur karier, nie powinni mieć żadnych problemów w zrozumieniu jego założeń oraz we wdrożeniu go w praktyce swojej instytucji.

Elementy, które składają się na produkt finalny, to:

1. Test diagnozujący kompetencje studentów. Składa się on z 276 pytań w podziale na dwa bloki: blok psychologiczny i blok kompetencji. W pierwszym bloku bada takie obszary, jak: asertywność, odporność na stres, kreatywne myślenie, poziom inteligencji emocjonalnej, role w zespole. W bloku kompetencji skupiono się na przetestowaniu motywacji do pracy, obowiązkowości, znajomości zasad przedsiębiorczości, umiejętności poszukiwania pracy oraz kompetencjach osobowościowych do wykazywania postaw przedsiębiorczych.

2. Arkusz wyników. Jest to karta, na której zapisywano wyniki w podziale na mocne strony i obszary do pracy.

3. Karta wsparcia i rozwoju. Po przeanalizowaniu wyników proponowane wsparcie będzie szyte na miarę - jest to innowacyjne w stosunku do dotychczas stosowanych metod. W karcie zawarto również opis aktywności własnej i pomysły studenta na podnoszenie swoich kompetencji.

4. Karta ewaluacyjna (wypełniana wspólnie ze studentem). Służy do opisu zmiany w dotychczas deficytowych obszarach. Jest to informacja zwrotna zarówno dla pracownika biura karier, jak i studenta na temat skuteczności podjętych działań i stopnia podniesionych kompetencji. Uczy studenta aktywnej postawy w kolejnych etapach kariery z uwzględnieniem idei kształcenia przez całe życie.

5. Referencje biura karier. To innowacyjna, pionierska propozycja służąca wzmocnieniu pozycji studenta wychodzącego na rynek pracy. Dokument zawiera pełny, szczegółowy opis mocnych stron i kompetencji studenta wraz z potwierdzeniem uczestnictwa w programie.

Oczywiście $\mathrm{w}$ trakcie testowania i eksperymentalnego wdrażania modelu zdawano sobie sprawę z występowania czynników, które mogą utrudnić lub ułatwić wdrożenie modelu. Stąd też dołożono wszelkich starań, aby przygotowany algorytm nie był skomplikowany, nie wymagał wprowadzania zmian prawnych ani organizacyjnych, lecz był elastyczny - podatny na modyfikacje, zwłaszcza uzupełnienia. Można go przedstawić następująco:

- student zgłasza się do biura karier - następuje szczegółowe przedstawienie programu, podpisanie zgody na badania i przetwarzanie danych osobowych oraz deklaracji uczestnictwa w programie,

- wypełnienie testu diagnozującego,

- pracodawcy współpracujący z biurem karier uczestniczą w ocenie studenta w czasie assessment centre i symulacji rozmowy kwalifikacyjnej, opinie te są składane w indywidualnej teczce (wraz ze zgodą i deklaracją),

- po sprawdzeniu testu diagnozującego wyniki opisywane są w arkuszu wyników, który uwzględnia opis mocnych stron, opis obszarów do wsparcia/pracy, in- 
formacje zwrotne od pracodawców z rozmów kwalifikacyjnych i assessment centre,

- pracownik biura karier uzupełnia wskazania w karcie wsparcia i rozwoju,

- arkusz wyników oraz karta wsparcia i rozwoju omawiane są wraz ze studentem - po kolei analizowane są zalecenia zawarte w karcie,

- biuro karier wspiera studenta w realizacji zaleceń,

- do indywidualnej teczki docierają wszystkie informacje zwrotne,

- pracownik biura karier wraz ze studentem wypełniają kartę ewaluacyjną,

- karta ewaluacyjna wraca do teczki,

- na podstawie wszystkich danych wystawiane są referencje biura karier.

Reasumując, stwierdza się, że oferowane w ramach modelu wsparcie wykracza poza działania informacyjno-organizacyjne i uwzględnia dynamikę zmian zachowań i postaw studentów koniecznych z punktu widzenia odniesienia przez nich sukcesu na rynku pracy. Jest to innowacyjne i kompleksowe podejście do potrzeb młodych ludzi wchodzących na rynek pracy. Na podstawie danych pochodzących od samych studentów, pracodawców i pracowników akademickich biur karier biorących udział w testowaniu można stwierdzić, że proponowane rozwiązanie jest bardzo dobrze dopasowane do wyzwań związanych z wejściem studentów na rynek pracy i powinno być powszechnie stosowane przez akademickie biura karier.

\section{Zakończenie}

Przedstawione wyniki badań i analiz wskazują, że zachodziła potrzeba stworzenia jednolitej i systemowej metody wsparcia studentów ostatniego roku szykujących się do wyjścia na rynek pracy, często do tego nieprzygotowanych. Na podstawie kontaktów z uczelniami zagranicznymi można również stwierdzić, że proponowana metoda wsparcia może być unikatowa w skali europejskiej.

Na podstawie zebranych i przeanalizowanych w ramach ewaluacji danych można wnioskować, że model jest rozwiązaniem efektywnym. Na jego efektywność wpływają szczególnie jego adekwatność i jego potencjalna skuteczność - jest to rozwiązanie, które w dużym stopniu odpowiada na potrzeby studentów wchodzących na rynek pracy. Koniec studiów i początek życia zawodowego stanowi dla młodych ludzi bardzo duże wyzwanie psychologiczne. Jest to koniec formalnej edukacji i przejście w nowy etap życia, co może wywoływać niepokój i poczucie zagubienia w rzeczywistości, w której obowiązują zasady funkcjonowania często odmienne niż $\mathrm{w}$ ramach instytucji edukacyjnych. Jedną z najważniejszych różnic między funkcjonowaniem $\mathrm{w}$ instytucji edukacyjnej a funkcjonowaniem $\mathrm{w}$ miejscu pracy jest stopień wsparcia, jakiego oczekują młodzi ludzie, poruszając się po rynku pracy. Istniejące rozwiązania w tym zakresie w dużej mierze nie biorą pod uwagę, że student może planować założenie własnej firmy. W tym wypadku bez konkretnego i, co ważne, kompetentnego wparcia osoby te mogą być narażone na duży stres 
i zwiększone prawdopodobieństwo niepowodzenia działań, co w konsekwencji wywoływać może frustrację i wzmagać poczucie zagubienia w samodzielnym życiu.

Model, który pozwala w sposób kontrolowany, w bezpiecznym otoczeniu poznawać realia rynku pracy, jest szczególnie wartościowy, umożliwiając uzyskanie rzetelnych informacji o atutach i słabych stronach, których poprawa pozwoli na zwiększenie szans na sukces w życiu zawodowym. Ponadto wsparcie w ramach modelu często uświadamia młodym ludziom, że koniec studiów nie jest końcem ich edukacji, gdyż rynek pracy, w dobie gospodarki opartej na wiedzy, wymaga ciągłego rozwoju kwalifikacji i kompetencji. Informacje uzyskane w ramach wsparcia przez uczestników projektu pozwalają im w sposób bardziej świadomy i zgodny z indywidualnymi predyspozycjami kierować swoim dalszym rozwojem. Zalety tego modelu sprawiają, że dodatkowy koszt czasowy przy wdrożeniu modelu wydaje się uzasadniony. Należy przy tym zwrócić uwagę, że model jest nie tylko alternatywą dla aktualnych form wsparcia, np. rozmów w ramach doradztwa zawodowego, ale w dużej mierze jest poszerzeniem oferty o nowy rodzaj wsparcia, w duży stopniu dopasowany do realnych potrzeb studentów.

\section{Literatura}

Arent A., Walczyna A., 2015, Mity przedsiębiorczości a postawy studentów wobec własnej działalności gospodarczej, Humanities and Social Sciences, 22 (2/2015).

Drucker P., 1992, Innowacja i przedsiębiorczość, PWE, Warszawa.

Gibb A.A., 1996, The Enterprise Culture and Education, Durham University Business School, Durham.

Klonowska-Matynia M., Palinkiewicz J., 2013, Przedsiębiorczość w teorii ekonomicznej, Zeszyty Naukowe Wydziału Nauk Ekonomicznych Politechniki Koszalińskiej, nr 17, s. 30-33.

Maciejczyk A., 1996, Kwalifikacje pracowników - oczekiwania pracodawców. Zmiany na rynku pracy a kształcenie zawodowe, Instytut Badań Pedagogicznych, Warszawa.

Minniti M., Bygrave W., 2001, A Dynamic Model of Entrepreneurial Learning. Entrepreneurship Theory and Practice, Baylor University.

Piecuch T., 2010, Przedsiębiorczość. Podstawy teoretyczne, C.H. Beck, Warszawa.

Studenci ostatniego roku szkół wyższych - pracodawcy czy pracownicy?, 2015, Pentor International Poznań, Poznań.

Targalski J., Kosała M., Pichur A., 2007, Postawy przedsiębiorcze wśród studentów kierunku ekonomia Akademii Ekonomicznej w Krakowie. Analiza wyników badań, [w:] Ksztaltowanie postaw przedsiębiorczych a edukacja ekonomiczna, P. Wachowiak, M. Dąbrowski, B. Majewski (red.), Fundacja Promocji i Akredytacji Kierunków Ekonomicznych, Warszawa. 